\author{
Jorge Augusto Tirado \\ Universidad de los Andes, Colombia \\ jo-tirado@uniandes.edu.co
}

\title{
La función política del control constitucional en Colombia 1910-1930
}

\begin{abstract}
Some of the democratic accomplishments of the Colombian constitutional reform of 1910 included: the creation of public actions of unconstitutionality, the separation of public powers, the independence of administrative entities, electoral guarantees, and freedom of the press. This paper reviews the role of Colombian constitutional control between 1910 and 1930 and concludes that most cases heard and decided during that period of time were not consistent with the major concerns and discussions of the constituency at the time.
\end{abstract}

Key words: Constitutional reform, Jurisprudence, National Assembly, Supreme Court of Justice

\section{A modo de introducción}

La reforma constitucional de 1910 tenía como objetivos garantizar la paz entre los partidos políticos y la ampliación de los espacios democráticos de la vida nacional. Las guerras de finales de siglo XIX entre liberales y conservadores, la ausencia de una ley electoral justa que permitiera una competencia en igualdad de condiciones para acceder al poder, la subordinación del poder judicial frente a sus pares, la sujeción de la Constitución a las leyes por disposición expresa del Artículo 6 de la Ley 153 de 1887, la separación de Panamá, y más tarde la dictadura de Rafael Reyes (Correa, 1996) hicieron perentorio la convocatoria a una Asamblea Constituyente que adelantara los cambios que aparecían como impostergables.

Entre los grandes avances de esta reforma estuvo la creación de la acción pública de inconstitucionalidad que pretendía erigirse en una instancia adicional de discusión y deliberación entre los partidos políticos, y en un mecanismo de 
defensa del consenso alcanzado en el seno de la Asamblea nacional. ${ }^{1}$ Para ello, la nueva institución contemplada en el Artículo 41 del A.L 3 de 1910 previó la posibilidad de que los ciudadanos pudieran demandar las leyes y decretos que consideraran apartados o contrarios a las disposiciones constitucionales. Se quería por medio de la acción pública crear escenarios de confrontación democráticos e ideológicos, que ayudaran a que los actores políticos de la época dejaran a un lado las escaramuzas bélicas y disintieran dentro un ambiente republicano y civilista. Fue este el gran objetivo político que persiguió el constituyente con la creación de la acción pública de inconstitucionalidad (Rodríguez, 2005).

La acción apareció como un novedoso espacio e instrumento en el que los actores políticos de la época podían controvertir sus ideas ante un tercero neutral a sus propósitos, sin necesidad de apartarse de las normas democráticas y de la institucionalidad del Estado. Pretendía ser una vía de escape y oxigenación a la dinámica fratricida de las guerras civiles entre los partidos políticos que amenazaban con disolver el territorio nacional.

En los primeros 20 años de existencia de la acción pública de inconstitucionalidad, ésta fue utilizada por diversos actores que acudían a ella para litigar una cantidad considerable de derechos, presentándose por consiguiente decisiones de la Corte Suprema de Justicia en los más variados temas.

La creación de la acción pública tenía un claro propósito político: establecer una instancia de balanceo y discusión institucional (adicional a las clásicas) entre los partidos políticos, que sirviera de garantía de la paz alcanzada. Contrario a lo que se creería, la jurisprudencia constitucional que va de 1910 a 1930 no tiene como denominador común una defensa de las reformas constitucionales logradas en el Acto Legislativo No. 3 de 1910 por parte de los actores o accionantes, pues la mayoría de casos litigados en el período examinado se sustraen del gran objetivo político con el que fue creada la mencionada acción de inconstitucionalidad.

1 El consenso alcanzado en la Asamblea Nacional de 1910 refleja el ideario reformista de la Unión Republicana: "b. Establecimiento de la responsabilidad del presidente de la República para todos sus actos administrativos y políticos; c. Prohibición absoluta de que el presidente de la República, o el que por cualquier motivo haga sus veces, pueda ser reelegido para el puesto en el período inmediato; d. Nombramiento por el Congreso o por otra entidad, de los suplentes que deban reemplazar al presidente de la República, pero en ningún caso por el mismo presidente; e. Reunión anual de las cámaras legislativas; f. Independencia efectiva del poder judicial, de manera que ni por nombramiento, ni por ningún otro motivo penda del Poder Ejecutivo, ni pueda ser supeditado por éste; g. Libertad de imprenta, con responsabilidad efectiva y pronta frente al Poder judicial; h. Organización de un sistema electoral con independencia de los demás poderes públicos, y sustraído de toda influencia oficial. Es entendido que el derecho al sufragio quedará en suspenso para los individuos de tropa del ejército, como consecuencia del precepto constitucional que declara que el ejército no es cuerpo deliberante; i. Atribución a las Cámaras para dar votos de censura al Ministerio o a uno o más de los Ministros del Estado; j. Elección del Procurador General de la Nación por la Cámara de Representantes" (Rodríguez, 2005 : 227). 
Sin embargo, se presentan en el período histórico analizado tres escenarios constitucionales en los que claramente los accionantes litigan en favor de la paz política y el consenso alcanzado en la Asamblea Nacional de 1910. Las líneas jurisprudenciales que componen estos escenarios, que atienden a preocupaciones y conflictos anteriores a la creación de la acción, son menos extensas que las surgidas con posterioridad, siendo estas decisiones no menos importantes por el papel que jugaron en el mantenimiento de la paz y en el origen de una democracia material y no sólo formal.

Los escenarios litigados en favor de la paz entre partidos políticos y el consenso alcanzado en la Asamblea Nacional de 1910 son los siguientes: 1. Separación de las ramas del poder público e independencia de las entidades de la administración; 2. Garantías electorales y libertad de prensa; 3. Tensiones entre centralización y descentralización y división territorial.

\begin{tabular}{|l|c|}
\hline \multicolumn{1}{|c|}{ Escenarios constitucionales } & Número de Casos litigados \\
\hline $\begin{array}{l}\text { Separación de las ramas del poder público } \\
\text { e independencia de las entidades de la } \\
\text { administración }\end{array}$ & 11 \\
\hline Garantías electorales y libertad de prensa & 3 \\
\hline $\begin{array}{l}\text { Tensiones entre centralización y descentrali- } \\
\text { zación y división territorial }\end{array}$ & 4 \\
\hline
\end{tabular}

\section{Separación de poderes e independencia institucional}

El clamor por un modelo de Estado en el que el poder del ejecutivo estuviera limitado por una separación real de los poderes públicos, en el que la injerencia del gobierno central sobre el Congreso no fuera total, hasta el punto de definirle su propia agenda, y en el que la rama judicial alcanzara una independencia efectiva que la extranjera de la minoría de edad frente a sus pares, era una constante en las exigencias de los liberales y los conservadores históricos de la época. Ejemplo de ello son los documentos publicados en 1896 titulados "Motivos de disidencia," redactados por Carlos Martínez Silva, y "A mis amigos políticos", de autoría de Marceliano Vélez, así como el documento que resultó de la Convención Liberal del 15 de agosto de 1897. En los textos aludidos, la preocupación comentada es explícita. Martínez Silva criticaba "la pérdida de independencia del poder judicial” (Correa, 1996 : 28), y Marceliano Vélez en sus observaciones al régimen regenerador pedía "la independencia del poder judicial y del Ministerio Público" (Correa, 1996 : 27).

El principio de separación de poderes estaba contemplado en el Artículo 57 de la Constitución de 1886, pero sólo con la creación de la acción pública de inconstitucionalidad en la Asamblea de 1910 y el ejercicio de ésta por parte de los ciudadanos contra leyes y decretos que pretendían desconocerlo, se hace 
vinculante para las actuaciones de los poderes públicos en Colombia. Así lo muestra nuestra investigación jurisprudencial entre los años de 1910 y 1930.

En sentencia de 23 de marzo de 1914 la Corte Suprema declara inexequible el decreto ejecutivo 87 de 1914 con el cual el gobierno nacional nombraba a Francisco Restrepo Plata agente fiscal en Londres. La declaración de inconstitucionalidad se funda en dos argumentos: en primer lugar, las agencias fiscales habían desaparecido de la estructura administrativa del ejecutivo por derogatoria de la Ley 18 de 1909, por lo que no se podía mediante decreto revivirlas; además de que, como lo expresa la Corte con vehemencia, es al cuerpo legislativo a quien corresponde, de acuerdo con el numeral 7 del Artículo 76 de la Constitución "crear todos los empleos que demande el servicio público, y fijar sus respectivas dotaciones".

El primero de los argumentos envía una señal clara al ejecutivo. La base legal sobre la que se apoyan los decretos ejecutivos no es suficiente para revivir o crear cargos que han sido anulados, es decir, que la simple voluntad del gobierno de nombrar a un ciudadano no trae consigo la creación de ese cargo, ni sus funciones y dotaciones. En segundo lugar, la Corte es clara al decir que la Constitución contiene una repartición de funciones y competencias que debe ser respetada para el buen funcionamiento del Estado, cuando deja en claro que es función privativa del Congreso la de crear los empleos públicos, y que, en consecuencia, solo él podrá hacerlo. Contiene esta sentencia una demarcación de competencias entre el legislativo y el ejecutivo en materia de creación de cargos, que en el caso tratado se han visto confundidas y que la Corte quisiera ver separadas. Dice la Corte que:

[...] cuando el Poder Ejecutivo dictó, en enero último, el Decreto acusado, la única Ley vigente sobre la materia era la 18 de 1909, de que se acaba de hablar; por consiguiente aquel carece de facultad constitucional o legal para dictar decreto sobre nombramiento de Agente Fiscal en el extranjero, porque este empleo está suprimido de conformidad con lo que establece la citada Ley 18 de 1909, y es al Cuerpo Legislativo a quien corresponde según el numeral 7 del Artículo 76 de la Carta Fundamental crear todos los empleos que demande el servicio público, y fijar sus respectivas dotaciones (Gaceta Judicial, $31: 21)$.

La Corte Suprema observa con recelo las pretensiones del Presidente de la República y del ejecutivo de ampliar la capacidad nominadora que el constituyente le ha concedido, por medio de la expedición de decretos ejecutivos en los cuales efectúa nombramientos. 
Es diciente, entonces, que en el Acuerdo 54 de 12 de diciembre de 1919 la Corte declare inexequible el decreto 1289 de 1919 en el que el ejecutivo nombraba un consejero de Estado. Aduce la Corte que:

[...] el congreso no puede legislar de propia autoridad respecto de la composición de entidades políticas, menos puede aceptarse que la delegación al Presidente de la República contenida en el ordinal 11 del Artículo 68 del Código de Régimen Político y Municipal, consienta entenderse en el sentido de que aquel alto Magistrado pueda llevar al Consejo de Estado un miembro interino no autorizado por el constituyente ni cuyo nombramiento se haya delegado por él a ninguna de las cámaras (Gaceta Judicial, 27 : 218).

El sentido de la decisión es claro: es inconstitucional que se legisle directamente sobre la composición de una entidad política; no se admite que con la expedición de una ley se llegue al nombramiento directo de un funcionario en una corporación. Dice la Corte que no puede hacerlo el legislador, ni mucho menos el Presidente de la República con la expedición de un decreto alegando una supuesta competencia que le concedería el Artículo 68 del Código de Régimen Político y Municipal.

Sin embargo, es una decisión dividida y salvan voto los magistrados Diago y Samper argumentando que agotadas las previsiones de la ley para suplir vacancias de los designados a cargos de la presidencia en el Consejo de Estado, puede el Presidente de la República en uso de las facultades que le da la Ley 4ª de 1913 (C.R.P.M) suplir con miembros interinos esta vacancia, única alternativa para que el Consejo de Estado no deje de operar y no incumpla sus importantes tareas de Estado. Dicen los magistrados mencionados en su salvamento de voto que:

[...] estas disposiciones tienen precisamente por objeto llenar cualquier vacío que entorpezca la Administración Pública, y suplir las deficiencias que lo inesperado y lo fortuito traigan consigo [...] Si el Poder Ejecutivo hubiera nombrado un suplente del respectivo Designado para que, en lo relativo a sus funciones de Consejero, integrara el Consejo, podrían tener alguna fuerza las razones que aduce la Corte; pero como el nombramiento hecho en el señor doctor Ismael $\mathrm{E}$. Castro tiene el carácter de interino por falta del respectivo suplente, el Decreto acusado está dentro de las facultades constitucionales y legales del Presidente de la República (Gaceta Judicial, 27: 220).

La posición mayoritaria prefiere proteger la independencia del Consejo de Estado (considerado para la época órgano político) así éste tenga problemas 
para completar su composición, y no delegar en el ejecutivo el nombramiento directo de consejeros por considerar que constituiría una intromisión en las labores de una entidad independiente, además de no estar el Presidente de la República autorizado para hacerlo por las normas constitucionales y legales.

La sentencia de 5 de abril de 1923 confirma la intención de la Corte de que el ejecutivo desarrolle sus competencias nominadoras dentro del marco constitucional. En este caso el general Ernesto Barrero demanda el decreto 82 de 1921. La Corte lo declara inexequible por cuanto éste asciende al capitán Leónidas Flórez Álvarez al grado de mayor, haciendo uso de las facultades presidenciales consignadas en el ordinal 7 del Artículo 120 de la Constitución de 1886, relativas a la facultad de conferir grados militares, pero lo hace violentando la Ley 23 de 1916 que regula la materia y que establece que para ascender a un capitán a mayor se requiere que haya servido cinco años, y que en dos de ellos haya ejercido el mando efectivo de una Unidad; requisitos con los que no cumple el capitán beneficiado con el decreto de ascenso. En este caso la acción pública se utiliza por un funcionario del Estado directamente subordinado al Presidente como lo es un General de la República para disentir de las decisiones del ejecutivo, manifestando abiertamente que las facultades presidenciales de orden constitucional para conferir grados militares se habían ejercido contrariando la legislación vigente.

En Acuerdo 36 de 27 de junio de 1918 el demandante Domingo Dueñas (juez del circuito de Leiva, distrito judicial de Tunja) acusa el Artículo 5 de la Ley 73 de 1917. El actor:

[...] se funda en que el período legal de los Jueces, según el Artículo 56 de la Ley 32 de 1907, es de dos años, a partir del 1 de julio de mil novecientos diez y siete; y que si se llegara a cumplir el artículo acusado, se verificaría necesariamente una suspensión del Juez en sus funciones, y por lo mismo, sería privado del sueldo que le corresponde como tal (Gaceta Judicial, 26: 297).

Que esto pugna con el Artículo 160 de la Constitución que quiere darle al poder judicial la estabilidad y respeto que se merece. Agrega que la única eventualidad bajo la cual un juez puede ser declarado insubsistente es que se configuren las causales contempladas en los Artículos 5 y 6 del Código Judicial, y que el superior jerárquico hiciera la declaratoria correspondiente.

La Corte decide declarar inexequible el artículo 5 de la Ley 73 de 1917 porque a juicio de la opinión mayoritaria de la Corporación el legislador modificó los distritos y circuitos judiciales sin respetar el período de los funcionarios judiciales en curso, es decir, quiso que entrara a regir la reforma territorial antes de cumplirse el período para el cual fueron nombrados los jueces del circuito. 
Por lo anterior, consideraron la disposición demandada contraria al Artículo 160 de la Constitución de 1886 que disponía que "los magistrados y jueces no podrán ser suspendidos en el ejercicio de sus destinos sino en los casos y con las formalidades que determinen las leyes, ni depuestos sino a virtud de sentencia judicial".

En esta ocasión la Corte sostuvo un pulso interno por lo que podemos llamar una tensión entre el principio de separación de poderes y la facultad constitucional del Congreso de modificar las divisiones territoriales consignadas en el Artículo 7 de la Constitución de 1886. Esta tensión originó un salvamento de voto conjunto de los magistrados Pardo, Samper y Diago, en el que argumentaron que sí le era posible al Congreso modificar la división territorial general contemplada en el Artículo 7, con más razón la división judicial del Artículo 153 de la Constitución. Lo contrario sería pensar que un cambio urgente en la división territorial no podría hacerse por existir magistrados o jueces a los que el período está por vencérseles.

La Corte le otorgó mayor importancia a la separación de poderes, por cuanto la historia política del país mostraba a este principio como una conquista democrática ${ }^{2}$ que debía ser salvaguardada, incluso si para hacerlo era necesario hacer una interpretación restrictiva de los Artículos 7 y 153 de la Constitución nacional. No querían dejarse los períodos de los jueces del circuito al vaivén de las decisiones del legislador, porque esto equivaldría a una fuerte injerencia del legislativo en el poder judicial, y casi a una subordinación laboral directa, toda vez que el legislativo podría alterar los períodos de los jueces modificando la división territorial judicial. Se quería erradicar la práctica de la trashumancia "que le permitía al gobierno trasladar los jueces de un distrito a otro a su amaño" (Correa, 1996 : 19).

La jurisprudencia de la época quiso preservar la independencia del poder judicial frente al ejecutivo. No permite intervenciones del gobierno en la justicia que no estén debidamente autorizadas o soportadas por la legislación. Lo anterior puede verse en el Acuerdo 40 de 12 de diciembre de 1918 por el cual se declara inexequible el inciso final del Artículo 1 del decreto 82 de 1918 debido a que la Ley 51 de 1917 le dio la facultad al Presidente de:

[...] reorganizar los servicios administrativos en los ramos de su dependencia, con el fin de hacer economías, para lo cual podrá reducir sueldos, suprimir empleos, variarles la denominación, reducir varios

2 A lo largo del texto se le llama conquista democrática a las reformas constitucionales que tuvieron lugar en la Asamblea Nacional de 1910 que propendían por una segmentación del poder estatal y por una repartición de las funciones constitucionales. Reformas en este sentido evitaban la dinámica vencedor- vencido bajo la cual a los actores políticos derrotados sólo les quedaba soportar las injusticias del régimen. En este sentido la expresión conquista democrática estaría ligada al concepto de democracia liberal. 
en uno solo y distribuir funciones entre los que queden (Gaceta Judicial, $26: 380)$.

De donde es claro que no podía extenderse a funcionarios del poder judicial, contraviniendo así el Artículo 57 de manera directa (separación de poderes) y de manera indirecta el ordinal 7 del Artículo 76 que dispone "que corresponde al congreso crear por medio de leyes, todos los empleos que demande el servicio público $[\ldots] "$.

El salvamento de voto del Magistrado Méndez en esta decisión, nos muestra que la independencia del poder judicial en Colombia era incipiente para la época, y que sólo a partir de la Asamblea Nacional de 1910 y del mecanismo de defensa que significó para este propósito la acción pública se empezó a gestar una verdadera rama judicial. El salvamento de voto expresa que los subalternos son meros oficiales y que no ejercen la función jurisdiccional, razón por la cual el Presidente, en virtud del decreto acusado, podía entrar a reglamentarlos. Este salvamento proveniente de un magistrado de la más alta corporación de justicia nos ilustra sobre la precaria independencia que para los tiempos objeto de análisis tenía el poder judicial, y lo fácil que era para el imaginario colectivo aceptar injerencias y presiones infundadas del legislativo y el ejecutivo sobre la justicia.

Resulta curioso que la defensa que los ciudadanos hacen del principio de separación de poderes contemplado en el Artículo 57 de la Constitución de 1886, no se suscite en la mayoría de los casos expuestos por el ánimo republicano de hacer respetar los postulados constitucionales demandando leyes o decretos que pretenden desconocerlos. En su mayoría los casos analizados no se caracterizan por la motivación ciudadana de los actores, carente de interés particular, de atacar leyes y decretos infieles a las normas constitucionales.

En las Sentencias de 23 de marzo de 1914 y de 5 de abril de 1923, y en el Acuerdo 54 de 1919, se demandan actos administrativos de carácter particular en los cuales se efectúan nombramientos de personas. Por medio de ellos se nombra un agente fiscal en Londres y un Consejero de Estado, y se asciende al Capitán Leónidas Flórez. Los actores acuden a la utilización de una acción abstracta con el uso de argumentos constitucionales pero con claras motivaciones personales o particulares. Los conflictos que llevan a demandar tienen un origen espacio temporal muy definido; y en el caso de la Sentencia de 5 de abril de 1923 es un General quien pide que se declare inexequible un decreto, es decir, que se anule el ascenso a mayor de uno de sus subordinados.

En el Acuerdo 36 de 1918 se demanda una disposición general (Artículo 5 de la Ley 73 de 1917) argumentando que la norma acusada es inconstitucional porque modifica la división territorial judicial, desconociendo el período de magistrados y jueces; pero es claro que siendo el accionante Domingo Dueñas 
juez del circuito, está a su vez defendiendo su período particular y el derecho a continuar en su cargo.

En estos primeros 20 años de jurisprudencia constitucional, la Corte Suprema busca delimitar las competencias y funciones de las ramas del poder público, y proteger la independencia de las entidades del Estado por medio de la declaratoria de inexequibilidad de leyes y decretos que modifican la estructura de la rama judicial o la composición de entidades políticas; que confunden o superponen las funciones del poder público; o que efectúan nombramientos o ascensos sin fundamentos legales sólidos, queriendo exceder la capacidad nominadora atribuida por el constituyente al legislativo y al ejecutivo. La Corte Suprema de Justicia quiere ver diferenciado en la actuación práctica y cotidiana lo que el constituyente separó en el texto constitucional.

\section{Garantías electorales y libertad de prensa}

La aprobación de una ley electoral justa y democrática había sido una constante en las exigencias que los conservadores históricos y los liberales hacían a los gobiernos conservadores desde el año de 1886. En el documento de "Bases prácticas de gobierno y de administración", más conocido como "Bases”, suscrito por los jefes del conservatismo histórico, figuraba como una de sus aspiraciones "la organización de un sistema electoral libre de la influencia oficial" (Correa, $1996: 35-36)$.

Ante la iliquidez del gobierno central en 1898, el Presidente José Manuel Marroquín le solicitó al Congreso la autorización para una emisión en papel moneda. Rafael Uribe Uribe condicionó su apoyo a la aprobación de sus más reiteradas propuestas, entre las que se encontraba la "promulgación de una ley electoral diseñada para eliminar los abusos en las urnas" (Correa, 1996 : 39-40).

Un sistema electoral neutral, que dejará atrás las elecciones amañadas y las intervenciones fraudulentas del gobierno para imponer sus candidatos a los cuerpos colegiados de elección popular era una aspiración de las fuerzas políticas de oposición de la época. Su consecución fue uno de los puntos neurálgicos para lograr la paz entre los partidos políticos conservador y liberal, porque ambos sabían que constituía la garantía de poder competir en igualdad de condiciones dentro de las reglas democráticas sin tener que acudir a las vías de hecho para reclamar lo que no era posible por los mecanismos institucionales.

La defensa de esta conquista por lo ciudadanos, mediante la acción pública de inconstitucionalidad, es escasa, pero da lugar a decisiones vehementes por parte de la Corte Suprema. En Sentencia de 24 de abril de 1913 el ciudadano Marceliano Pulido pide se declaren inexequibles los Artículos 2, 3, 4 y 7 del decreto Ejecutivo 226 de 1913, reglamentario de la Ley 80 de 1910, argumentando que "el Artículo 2 del Decreto impone al Jurado Electoral la obligación de revisar el censo electoral y modificarlo, de acuerdo con el movimiento de 
población y renovación sucesiva del censo de ciudadanos vecinos del Municipio" y el "Artículo 3 del Decreto que se examina impone a los Jurados Electorales una obligación que no emana de la ley [...] Y como ello es así, resulta que en él se ha dictado un precepto legal que corresponde privativamente al Congreso, con arreglo a lo prescrito en el Artículo 181 de la Constitución" (Gaceta Judicial, 22: 50).

Para la Corte el citado decreto es inconstitucional porque de él emanan preceptos legales que hacen modificaciones a la Ley Electoral 119 de 1892, siendo el legislador el único facultado para hacerlo, imponiéndose obligaciones adicionales a los jurados electorales. Es por ello que contraría el Artículo 181 de la Constitución que establece reserva de ley para lo concerniente a elecciones y escrutinios. En el mismo sentido, dice la Corte, el Artículo 142 de la Ley 7 de 1888 dispone que las medidas que tome el gobierno en esta materia no podrán contradecir los mandamientos de la ley.

Debemos observar que el decreto 226 de 1913 contradice el Artículo 181 de la Constitución y varias leyes anteriores a los actos legislativos expedidos por la Asamblea Nacional de 1910, lo que quiere decir que las prohibiciones de que el gobierno pudiera por medio de decretos incidir en las legislación electoral eran muy anteriores a la creación de la acción pública y a la reforma constitucional de 1910. No obstante, es sólo con la creación de esta acción que las prohibiciones aludidas se hacen vinculantes, y se le imposibilita al gobierno que por medio de decretos atropelle al partido político opositor. Por lo demás, la Corte pone de presente una doble prohibición para el ejecutivo: la imposibilidad de dictar normas en materia electoral (prohibición constitucional), y de tomar medidas prácticas que se aparten de los mandamientos legales del legislador (prohibición legal).

Los ciudadanos Nemesio Camacho, Fabio Lozano y Luis de Greiff hicieron uso de la acción pública de inconstitucionalidad para salvaguardar el Artículo 22 del Acto Legislativo No. 3 de 1910, que establecía una inhabilidad para ser elegido senador o representante por departamento o circunscripción electoral, respecto de los ciudadanos que tres meses antes de las elecciones hubieran ejercido jurisdicción o autoridad civil, política y militar. Demandan la parte final del inciso 1 del Artículo 215 de la Ley 85 de 1916 porque relativiza y cambia la disposición constitucional mencionada al establecer que dicha autoridad debió ejercerse en la totalidad del territorio sujeto a la elección. La Corte en Acuerdo 30 de 29 de septiembre de 1917 acoge los planteamientos de la parte demandante cuando dice que lo dispuesto por el artículo acatado no fue la voluntad del constituyente, y es claro que el legislador sin fundamento alguno se apartó de ella.

El magistrado Rodríguez expresa en salvamento de voto a la decisión comentada que la disposición constitucional (Artículo 22 de A.L 3 de 1910) no 
es clara sobre si no puede ejercerse ese tipo de cargos en parte o toda la circunscripción, por lo que el legislador no ha hecho sino explicar lo que es oscuro en el precepto constitucional. Agrega que cuando la autoridad de un funcionario es muy limitada poco puede influir en los resultados electorales.

La Corte opta por una interpretación amplia del Artículo 22 del A.L 3 de 1910, porque lo que estaba en juego era una de las piezas medulares que mantenían la concordia y la paz entre partidos políticos. El entrar a relativizar los derechos y garantías electorales por medio de la interpretación constitucional tenía el riesgo enorme de ir reduciéndolos, y la potencialidad de quebrar el consenso alcanzado en la época por los liberales y conservadores. Los derechos y garantías para la competencia electoral entre partidos eran las columnas sobre las que se apoyaba el ejercicio pacífico de la democracia, y el desconocimiento de ellos por los jueces podía justificar el retorno a las guerras fratricidas de antaño y a la anarquía de finales de siglo XIX.

Las pocas sentencias de la Corte Suprema de Justicia en relación con los derechos y garantías electorales nos sugieren que la producción normativa del período que va de 1910 a 1930 respetó los pactos entre los partidos políticos, por lo que la acción pública no tuvo una utilización reiterada por parte de la ciudadanía en este escenario constitucional.

Llama la atención la casi nula reclamación del derecho a la libertad de prensa por medio de la acción pública de inconstitucionalidad. La prensa y los periódicos de la época eran los principales instrumentos para adelantar el proselitismo político, hasta el punto de que los periódicos se fundaban con objetivos políticos precisos que iban más allá del deber de informar, tales como defender las ideas liberales o conservadoras o impulsar determinada candidatura o facción dentro un partido político.

Tan sólo se registra una decisión de importancia en cuanto a la libertad de prensa. En Sentencia de 17 de noviembre de 1914 la Corte declaró inexequible el Artículo 1 de la Ley 59 de 1911 por contrariar el Artículo 42 de la Constitución que consagra la libertad de prensa en tiempos de paz, cuando dispone límites a la publicidad, estableciendo que sólo podrá hacerse con el nombre del periódico más no con el contenido del mismo. La Corte encontró que por medio de la ley citada se hacía una indebida restricción a la libertad de prensa, y más concretamente a la libertad de pautar.

Las normas constitucionales y legales que consagraban las garantías electorales y la libertad de prensa eran conquistas democráticas esenciales para mantener la paz entre los partidos políticos, y el clima de concordia y civilidad que reinaba en estos años posteriores a la Asamblea Nacional de 1910. Una libertad de prensa real era esencial para la promoción de candidatos y la divulgación de las ideas políticas, pero sólo con leyes electorales transparentes podía garantizarse que los representantes de los cuerpos colegiados fueran realmente los elegidos 
por el pueblo. La libertad de prensa y las leyes electorales justas eran puntos no negociables para los partidos políticos, y una arremetida del Congreso o del gobierno de turno contra ellos podía suscitar los conflictos de antaño.

\section{Tensiones entre centralización y descentralización y división territorial}

La Constitución de 1886 estableció "una forma de Estado, unitaria y centralista" (Rodríguez, 2005 : 222) que no fue reformada por la Asamblea Nacional de 1910. Dentro de los puntos que se ponían en consideración de la Asamblea por decisión del Presidente de la República Ramón González Valencia estaba el "restablecimiento de las Asambleas Departamentales y adopción de preceptos que aseguren la descentralización administrativa y la autonomía de los municipios" (Correa, 1996 : 149). Podía la Asamblea pronunciarse sobre este aspecto según se desprende del decreto 125 del 25 de febrero de 1910 mediante el cual se le convocaba y se fijaban los puntos que servirían de base para las reformas constitucionales de este cuerpo constituyente. No obstante, la Asamblea no hizo reformas considerables en esta materia, por lo que subsistió el marcado centralismo que venía de la Constitución de 1886 acompañado de una débil descentralización administrativa.

La jurisprudencia constitucional del período comprendido entre 1910 y 1930 permite inferir que las tensiones entre un acérrimo centralismo y una real descentralización permanecieron en las motivaciones de los accionantes, pero poco debate generaban sus demandas en el interior de la Corte, porque sus peticiones no encontraban sustento en el texto constitucional. Dicho de otra manera, subsistían los debates y los cuestionamientos en el país en relación con la forma de Estado más acorde con la realidad colombiana y más ajustada a la pronta resolución de los problemas regionales, pero las leyes y decretos de marcado acento centralista en nada se oponían con lo decidido por el constituyente. Es por esto que las demandas de los actores poco eco generaron en la Corte Suprema, apareciendo quien las impulsaba como un desconocedor de la Constitución nacional.

El doctor Esteban Jaramillo, en representación del departamento de Antioquia, solicita que se declare inexequible por inconstitucional el Artículo 15 de la Ley 12 de 1922 en cuanto el mencionado Artículo derogó el 22 de la Ley 6a de 1922 disminuyéndose la participación que según este Artículo corresponde a los departamentos "en el producto líquido del impuesto sobre la renta desde mil novecientos veintidós" (Gaceta Judicial, 30 : 33). El actor acompaña a la demanda ejemplares autenticados del Diario Oficial en que constan las normas mencionadas, y copias autenticadas de las Ordenanzas departamentales de Antioquia expedidas en 1922, "en las cuales se tuvo en cuenta la participación que la Ley 6 a de ese año dio a los departamentos en el producto líquido del impuesto 
sobre la renta, y tomó a su cargo el departamento los gastos que les impuso la misma Ley" (Gaceta Judicial, 30 : 33). Con esto quiere el actor demostrar que el departamento de Antioquia contaba con los recursos provenientes del impuesto de renta, hasta el punto que la Asamblea los había incluido en el presupuesto departamental por medio de ordenanzas.

En Sentencia de 26 de febrero de 1923 se niega la declaratoria de inexequibilidad del Artículo 15 de la Ley 12 de 1922 por cuanto el impuesto de renta es un impuesto nacional y no departamental, su el destino a inversiones departamentales es una cesión y no un derecho adquirido susceptible de protección. Cosa distinta, dice la Corte, es que el Artículo 16 de la ley mencionada respete dicha cesión cuando los departamentos hubieran pignorado lo que recibían por concepto de estos ingresos antes del 22 de marzo, por contrato que estuviera perfeccionado antes de esa fecha.

La discusión que subyace versa sobre la poca recepción que las entidades territoriales tienen de los tributos que pagan los colombianos. Lo que a su vez las hace dependientes económicamente del gobierno central y no les permite desarrollar soluciones eficaces a sus propios problemas. Sin embargo, no es este un debate que pueda darse ante la Corte en ejercicio de una acción en la que solo es posible poner de presente las infidelidades que las normas jurídicas tengan con la Constitución nacional.

La Corte Suprema en Sentencia de 4 de diciembre de 1925 declara exequible el Artículo 3 de la Ley 88 de 1923, porque si bien es cierto que una renta de carácter departamental le pertenece a los departamentos, la definición de su monto y cuantía debe venir determinado por una ley, así como el cobro y la manera de administrar esa renta. En otras palabras, aún cuando estos tributos les pertenecen a los departamentos en virtud del Artículo 56 del A.L 3 de 1910 es el legislador quien debe crear las contribuciones y el modo de percibirlas. La anterior jurisprudencia es clara: el legislador detenta la potestad impositiva del Estado, por lo que sólo él puede imponer impuestos.

El debate existente en el país entre adoptar un fuerte centralismo o un modelo de descentralizado en lo administrativo, se traducía también en discusiones sobre cuál debía ser la organización territorial ideal, o mejor, en qué términos debía darse la relación Nación-región. Como era el legislador quien estaba investido de la competencia para organizar los territorios, crear departamentos, municipios e intendencias, y agrupar municipalidades, la ciudadanía se preguntaba cuál era el margen de maniobra que tenía el legislador en estas materias, y hasta qué punto llegaba su discrecionalidad. iLimitaba la Constitución la competencia del legislador para organizar el territorio nacional?

Es eso lo que se debate en la Sentencia de 5 de diciembre de 1912 en la que Luis José Barros demanda la Ley 52 de 1912 que organizaba la intendencia de San Andrés y Providencia, aduciendo el argumento de que el legislador no 
podía crear entidades territoriales de este tipo, porque el Artículo 2 del A.L 3 de 1910 disponía que el territorio nacional se dividirá en departamentos, y estos en municipios o distritos municipales. La posición mayoritaria de la Corte fue que si bien la norma constitucional referida solo habla de departamentos, municipios o distritos municipales, esto no excluye la existencia de otras divisiones territoriales creadas por la ley, existentes al momento de expedirse el acto legislativo, como lo son las intendencias.

El magistrado Rodríguez en salvamento de voto expresa que tal como quedó el nuevo Artículo 6 de la Constitución después de la reforma del Artículo 2 del A.L 3 de 1910 sólo podía la ley reconocer dos entidades administrativas, a saber: departamentos y municipios; y de reformar el legislador el estado de una intendencia, sería para integrarlo a un departamento.

Como lo habíamos señalado antes, los casos decididos por la Corte Suprema de Justicia en temas vitales para la paz entre los partidos políticos, y relativos al consenso alcanzado en torno a las reformas constitucionales de 1910, es realmente escaso en el período que va de 1910 a 1930. Y si son escasas las decisiones en ese sentido, es precisamente porque estos temas no estuvieron dentro de las preocupaciones esenciales de los ciudadanos que acudieron a la acción pública en estudio.

Es en cierta medida paradójico, que la acción pública de inconstitucionalidad, que fue concebida por el constituyente como un mecanismo regulador de las discusiones y diferencias políticas entre los partidos conservador y liberal, y como un instrumento para que la ciudadanía pudiera salvaguardar las reformas constitucionales logradas en la Asamblea Nacional de 1910, hubiera sido utilizada en tan baja proporción con el objetivo para el que fue confeccionada por el constituyente.

Por el contrario, se presenta una explosión litigiosa en torno a nuevos temas, ajenos a las causas y motivos tradicionales que servían de detonante para los enfrentamientos entre liberales y conservadores; y que no estuvieron sujetos a reformas, ni a grandes discusiones en la Asamblea Nacional de 1910.

Pareciera que la Acción Pública creada en ese momento constituyente, y que tenía como principal objetivo el de defender las transformaciones constitucionales de la época y los acuerdos de paz entre partidos políticos, evolucionó con gran rapidez para convertirse en instrumento de intereses privados y particulares que encontraron en ella un mecanismo de contención del poder estatal, y más concretamente de las reglamentaciones y regulaciones que éste adelantaba al intervenir en la economía del país; desarrollando también con su ejercicio una oposición a la creación de nuevos impuestos.

La utilización de la acción pública con los objetivos antes mencionados se dio en los siguientes campos: 1. Libertad de industria (hoy de empresa); 2. Constitucionalidad de impuestos y tributos; y 3 . Derechos adquiridos y de propiedad. 


\begin{tabular}{|c|c|}
\hline Escenarios constitucionales & Número de casos litigados \\
\hline Libertad de industria & 13 \\
\hline Constitucionalidad de impuestos y tributos & 6 \\
\hline Derechos adquiridos y de propiedad & 22 \\
\hline
\end{tabular}

\section{Libertad de industria (empresa)}

La jurisprudencia constitucional de la Corte Suprema de Justicia en el período de 1910 a 1930 se caracteriza, en lo relativo a la libertad de industria, por un examen juicioso por parte de la corporación de las leyes y decretos demandados, intentado en cada caso establecer si las disposiciones acusadas constituyen legítimas intervenciones del legislativo o del gobierno en la actividad económica y empresarial, de acuerdo con el Artículo 44 de la Constitución de 1886, y más tarde con el Acto Legislativo 1 de 1918.

En Sentencias de 12 de julio de 1913 y 2 de septiembre del mismo año la Corte declara exequible el decreto ejecutivo 393 de 1913 al considerar que lo dispuesto en éste era un simple desarrollo de lo ya consagrado en el Artículo 12 del Código Fiscal y de disposiciones del Código de Minas que permiten establecer con certeza quién ha descubierto un yacimiento petrolífero, razón por la cual exige acompañar a la solicitud un análisis técnico demostrativo de que se trata de petróleo; la presentación de muestras de petróleo; y planos científicos del yacimiento, por lo que el ejecutivo no excede la potestad reglamentaria y no se viola el numeral 3 del Artículo 120 de la Constitución.

Esa Corporación encontró que las medidas tomadas por el Gobierno con el Decreto 393 de 1913 tan solo repiten lo contemplado en normas especiales que regulan la materia de minas en el país, además de no hacer más difícil la explotación de la actividad petrolífera, regulándola para que quienes dicen participar de ella deban comprobarlo y certificarlo ante las autoridades.

Busca con su jurisprudencia que las actividades económicas se desarrollen con transparencia, aprobando las reglamentaciones gubernamentales y las normas legislativas que así lo pretendan. Muestra de ello es la Sentencia de 30 de octubre de 1916 en la que se declara exequible el Decreto Ejecutivo 2146 de 1915 porque no viola la libertad de industria y sólo pretende impedir que se ingresen fármacos en envases que no les corresponden para evitar el pago de la tarifa de aduanas. El decreto acusado no genera una intervención inconstitucional en la industria, por lo que no es contrario al Artículo 44 constitucional, pues lo que se pretende es poner fin a la defraudación del fisco que se lograba estableciendo una denominación inexacta a los envases y por consiguiente a las medicinas. Agrega la Corte que el gobierno ejerce la competencia que le da el numeral 14 del Artículo 120 de la Constitución que impone el deber "de cuidar de la exacta recaudación y administración de las rentas públicas y caudales públicos". 
En Sentencia de 14 de noviembre de 1924 se abstuvo de declarar la inconstitucionalidad del Artículo 8 de la Ley 64 de 1923 por tener las medidas en él adoptadas origen en el legislativo, atribuyéndole a este cuerpo colegiado la posibilidad de decidir cuándo debe intervenir o no en la economía y la industria del país. En este caso, en el que actuaba Luis Corchuelo, la Corte decidió declarar la norma mencionada exequible, porque el legislador había considerado a las loterías de carteles como deshonestas por cuanto "generan pernicia y traen la ruina a las familias que las practican" (Gaceta Judicial, 31: 205), lo que no constituye atentado a la libertad de industria consagrada en el Artículo 44 constitucional.

Aún cuando la intervención que hace el Estado por medio de esta Ley podría estar avalada por el Acto Legislativo 1 de 1918, en la medida en que los argumentos que esgrime la Corte para su constitucionalidad podrían enmarcarse dentro de la moralidad pública, causa curiosidad que la razón por la que la Corporación considera la norma no violatoria de la libertad de industria sea la del amplio poder discrecional que le atribuye al legislador para decidir cuándo debe intervenir en ella. En esta Sentencia, más que reflexiones constitucionales para declarar la norma exequible, lo que hay es un argumento de autoridad institucional que considera que dentro de las funciones del Congreso está la de decidir qué industrias son contrarias a las buenas costumbres y perjudiciales para los intereses de los colombianos.

La Corte Suprema admite que se regule el ejercicio de las profesiones liberales pero no que se restrinja o circunscriba su ejercicio a determinadas zonas del territorio nacional. En el Acuerdo 5 de 1 de marzo de 1921, el señor Carlos J. Galindo demanda los Artículos 3 y 4 de la Ley 67 de 1920. El Artículo 3 demandado dice que

[...] toda persona que sin ser médico titulado hubiere obtenido permiso para ejercer la medicina, deberá presentar, durante los primeros noventa días de reunida la Junta, el respectivo permiso, para que ésta inscriba en la lista el nombre del agraciado y el lugar en que pudiere ejercer (Gaceta Judicial, 28 : 289).

El Artículo 4 dice así: "Autorízase a la Junta para retirar los permisos que se hayan expedido, siempre que ella crea que los agraciados no lo merezcan" (Gaceta Judicial, $28: 289$ ). El solicitante considera que la parte final del artículo transcrito limita el ejercicio de la medicina porque la Junta deberá señalarle el lugar en que puede ejercerla, y el actor considera que el legislador no está autorizado "para disponer que se señale el lugar para ejercer cualquier oficio u ocupación honesta" (Gaceta Judicial, $28: 289$ ).

La Corte declara exequibles los artículos mencionados porque éstos no establecen que la junta deba señalar el lugar en que el agraciado puede ejercer 
la medicina, sino que inscriba su nombre en la lista respectiva y el lugar sólo en el permiso que exhiba para ejercerla. En cuanto a la posibilidad de revocar el permiso que tiene la Junta (que establece el Artículo 4), es obvio que sea así, porque los permisos no constituyen títulos de idoneidad, por lo que la Junta puede perfectamente revocarlos.

Por el contrario, la Corte encuentra inexequibles las leyes y decretos que con sus estipulaciones hacen demasiado onerosa la explotación de una actividad económica, o que con su expedición generan regulaciones excesivas que bien podrían considerarse como intromisiones directas por parte del Estado en la actividad de los particulares. La Corte es celosa al proteger la libertad de empresa consagrada en el Artículo 44 de la Constitución y solo permite la intervención en este ámbito bajo las estrictas circunstancias que señala el Acto Legislativo 1 de 1918 y el 1 de 1921 (supervisión de la moralidad, salubridad y seguridad públicas).

El Acuerdo 10 de 30 de septiembre de 1921, el Acuerdo 3 de 24 de abril de 1922 y la Sentencia de 17 de agosto de 1926 son claros ejemplos de lo que la Corte de la época consideró como excesos en la reglamentación de una actividad económica, teniendo a veces como consecuencia el hacer su explotación demasiado onerosa.

En la primera de estas decisiones, Eduardo Zuleta Ángel como apoderado de Antonio J. Álvarez pide con éxito que se declare inexequible el Parágrafo 1 del Artículo 1 de la Ley 97 de 1920 por ser contrario al A.L. 1 de 1918 que restringe la supervisión por parte del Estado de la actividad de industria a cuestiones de moralidad, salubridad y seguridad públicas, lo que no autoriza, so pretexto de acometer estos fines, el imposibilitar la explotación económica de una actividad, como cuando se exige que la fundición del oro deba hacerse exclusivamente en las capitales de departamento, haciendo muy oneroso el desarrollo de la actividad para quienes llevan años ejerciéndola por fuera de los sitios señalados. La Corte acoge estos argumentos sobre la base de que las normas constitucionales no admiten que por medio de leyes se hagan restricciones de las actividades económicas que son susceptibles de desarrollarse en determinados territorios. No hay pues razones válidas de orden constitucional para aceptar que la fundición de oro pueda ejecutarse en las capitales de departamento y no en las poblaciones que no tengan esta condición.

Es similar lo que ocurre en el Acuerdo 3 de 24 de abril de 1922. En él, Alfonso Villegas Restrepo y la Sociedad Pedro A. López y Compañía piden que se declare inexequible el Artículo 2 de la Ley 4⿳亠丷a de 1920 sobre transportes. A juicio de los actores, se excede el legislador en la capacidad de supervisión que le permite la Constitución, que debe estar atada al A.L 1 de 1918, cuando decide "que toda empresa que ejerza el transporte en los ríos navegables de la Nación, es empresa pública de transportes" (Gaceta Judicial, 27 : 125). Para los actores, es cierto que 
todas las empresas de transporte fluvial prestan un servicio general, obligatorio y abierto al público, de dónde no se sigue que todas las empresas de carácter privado que concurren en su prestación se conviertan en públicas por el sólo hecho de que el transporte constituya un servicio con finalidad pública. La Corte declara inexequible la norma acusada por las razones que alegaron los actores.

En Sentencia de 17 de agosto de 1926, la Corte Suprema de Justicia declara inexequible el inciso d. del Artículo 1 del Decreto 1093 de 1923 porque, tal como lo alega el actor Miguel Uribe Holguín, el disponer que los interventores puedan revisar los documentos de las empresas mineras para comprobar las aseveraciones que aquellos contengan, contraviene el Artículo 43 de la Constitución que establece que:

[...] las cartas y papeles privados no podrán ser interceptados ni registrados sino por la autoridad, mediante orden de funcionario competente, en los casos y con las formalidades que establezca la ley, y con el único objeto de buscar pruebas judiciales.

Esta decisión despierta discusiones en el interior de la Corte, como lo demuestra el salvamento de voto de Parmenio Cárdenas, quien considera que la norma acusada no es contraria al Artículo 43 de la Constitución, porque el literal d. del decreto acusado no se refiere a papeles privados, sino tan solo a los papeles en que se hagan aseveraciones por parte de los empresarios de platino que tengan que ver con exportaciones. El magistrado José M. Arango, en su salvamento de voto (en lo que hoy sería una aclaración de voto), afirma que las disposiciones acusadas afectan la libertad de industria, por cuanto, utilizando como pretexto la vigilancia y supervisión de una actividad para su correcto cumplimiento, se está haciendo una restricción indebida de una industria.

Dentro del auge industrial y comercial que vivía el país, para la época se gestaba una nueva actividad económica: la actividad bancaria o financiera. Se fundaron en Colombia entre 1870 y 1926 una gran cantidad de bancos, especialmente en la región de Antioquia y el eje cafetero. El Banco de Bogotá, en 1870; el Banco de Antioquia, en 1871; el Banco del Comercio, en 1896; el Banco de Manizales, en 1901; el Banco del Ruiz, en 1916; el Banco Alemán Antioqueño, en 1912; y el Banco Hipotecario de Medellín, en 1920, entre otros (Cinep, 1998: 60).

La acción pública de inconstitucionalidad fue utilizada por quienes adelantaban esta actividad económica como una instancia adicional en la que se debatían las leyes y decretos que reglamentaban esta materia. Por medio de la acción, los actores procesales litigaban sus intereses en el negocio, pidiendo la declaratoria de inconstitucionalidad de leyes y decretos que a su juicio les otor- 
gaban particulares ventajas a sus competidores, o que rebasaban la capacidad reguladora y de intervención que la Constitución le permitía al Estado.

El Acuerdo 11 de 22 de octubre de 1921 y la Sentencia de 12 de diciembre de 1925 son decisiones en las que los actores atacan una norma que consideran genera monopolio y otra que los deja expuestos a una mayor competencia en el mercado, respectivamente. Son entonces dos decisiones que se originan en la creencia de los actores de que con la expedición de esas leyes se les otorga claras ventajas a sus competidores. En la primera de ellas, Jorge Martínez pide se declare inexequible el numeral 10 del Artículo 2 de la Ley 51 de 1918, alegando que esta norma crea monopolios cuando abre la posibilidad de que se emitan determinados certificados.

La Corte no acoge sus argumentos porque:

[...] en primer lugar, la facultad de emitir certificados no se da a un solo banco o a bancos determinados, que sería lo que podría entrañar monopolio o privilegio... En segundo lugar, la facultad de emitir certificados sobre valores que se reciben en depósito no es atributo o función exclusiva del gobierno [...] no puede decirse con fundamento que con la conferida a los establecimiento de crédito el gobierno dé lo que concierne a él como representante de la Nación (Gaceta Judicial, 29 : 61).

Para la Corte no puede existir monopolio cuando la posibilidad de emitir cierto género de certificados se le da a varios establecimientos bancarios a la vez, además de que concediendo esta función el gobierno no pierde la competencia para emitir también este tipo de certificados.

En Sentencia de 12 de diciembre de 1925, la Corte Suprema no atiende los planteamientos del demandante que pide se declare inexequible el Artículo 1 de la Ley 45 de 1923 que abre la posibilidad de que las personas naturales puedan prestar los servicios de un establecimiento bancario. Para la Corte, el Artículo es constitucional porque, al contemplar la posibilidad de que un individuo se asimile a establecimiento bancario, tan sólo abre la puerta para que un individuo pueda prestar todos los servicios de un establecimiento porque tenga el dinero para hacerlo, sin que quede exento de unos requisitos y del cumplimiento de la ley.

En esta Sentencia, la Corte deja en claro que el Estado puede entrar a regular la actividad bancaria con cierta minucia cuando avala la prohibición de que las reservas de los establecimientos bancarios no pueda destinarse al pago de dividendos de los socios por constituir una garantía para los mismos accionistas y para el público en general. En este mismo sentido, la Corte en Sentencia de 25 de septiembre de 1925 declara exequible el Artículo 53 de la Ley 68 de 1924, por cuanto el ejercicio bancario está sujeto a restricciones y regulaciones en 
materia de seguridad pública por autorización del Acto Legislativo 1 de 1921, por lo que la concretización de esta facultad por parte del Congreso no toca con derecho adquirido alguno, y debe aplicar para los bancos constituidos con anterioridad a la vigencia de esta Ley.

Las sentencias reseñadas son producto del litigio de actores que ponen de presente en los distintos casos los particulares motivos e intereses económicos que los mueven. Estos no se preocupan por esconder sus intereses personales en motivaciones generales y abstractas; más bien lo que hacen es invocar las normas constitucionales que les garantizan de manera general e impersonal el derecho litigado que pretenden se les proteja, en este caso la libertad de industria, protegida en el Artículo 44 de la Constitución y en los Actos Legislativos 1 de 1918 y 1 de 1922. Es claro que la acción pública se estaba constituyendo en un mecanismo eficaz para controvertir las intromisiones en la industria por parte del Estado no sustentadas en normas constitucionales, y en un instrumento de contención del poder regulador estatal de la economía y la industria, actividades que para la época estaban en ascenso.

En Cartagena en el año de 1904, José Vicente Mogollón, bajo la razón social J. V. Mogollón y Cía., abre almacenes para la venta de útiles de escritorio, papelería y mercancía miscelánea, así como "taller de encuadernación, fabricación de libros en blanco y factura y quizá la primera prensa tipográfica" (Dávila, 2003 : 716-717). Para esta época en esta misma ciudad la familia Del Castillo iniciaba la importación de telas desde Saint Thomas, y exportaba tabaco y caucho. También fueron los grandes impulsores de la Cartagena Oil Refining Co. (Dávila, 2003 : 585) y accionistas de la Colombian Sugar Co. En 1894 Adolfo Held funda en Barranquilla la Casa comercial A. Held y Cía. En Cali Manuel Carvajal Valencia constituye en 1907 la Sociedad Carvajal; y Jorge Garcés Borrero funda en 1925 los Laboratorios JGB y el Banco del Pacífico en 1911, que posteriormente se convertiría en el Banco de Colombia en 1928. En esta misma ciudad, Ulpiano Lloreda inicia las más variadas actividades económicas: la empresa de transporte fluvial río Cauca, trilladoras de café, fábrica de velas y jabones, fábrica de cigarrillos y de clavos, además de fundar el diario El País en 1918. En Medellín, Ricardo Olano Estrada inicia la Compañía de Fósforos Olano en 1908 y revive la producción a gran escala de velas esteáricas (Dávila, 2003).

Por su parte, Carlos E. Restrepo, político, constitucionalista y principal líder de la Unión Republicana (grupo impulsor de las reformas constitucionales de 1910), fue a la vez uno de los más importantes empresarios de finales del siglo XIX y principios del XX. En 1890 fue representante de la casa comercial Babin Frises \& CIA; en 1891 fue presidente de la Sociedad de San Vicente de Paúl de Medellín, empresa pionera en el campo textil en Antioquia (Dávila 2003 : 448). En 1902 fundó la Librería Restrepo y el periódico Vida Nueva en compañía del General Mariano Ospina Vásquez. Culminado su periodo presidencial, fundó en 
el año de 1919 la Compañía Colombiana de Tabaco (Coltabaco), adquiriendo el 10\% de las acciones; y en 1917 constituyó la Sociedad Restrepo \& Cía. que sirvió de agencia del Banco de Bogotá. Asimismo fue elegido en 1927 como Presidente del gremio de los cafeteros (Dávila, 2003).

Este auge de la industria y el comercio en gran medida explica el litigio recurrente de empresarios que reclamaban de la Corte Suprema de Justicia la declaración de inexequibilidad de normas que a su juicio dificultaban el ejercicio de actividades económicas.

\section{Constitucionalidad de impuestos y tributos}

En los primeros 10 años de existencia de la acción pública de inconstitucionalidad, diversos actores acuden a ella para atacar leyes y decretos que crean nuevos impuestos y contribuciones. Lo hacen usando un lenguaje constitucional que cuestiona la competencia del ejecutivo para crear contribuciones de este tipo, así como la creación abstracta de tributos por parte del legislativo sin la determinación de los elementos de la obligación tributaria como lo son el sujeto pasivo, sujeto activo, hecho generador, tarifa y base gravable (Bravo, 1997).

La Corte Suprema tiende a ser estricta en el examen de constitucionalidad de los impuestos creados por decreto declarándolos casi siempre inexequibles, argumentando que la creación de tributos es una facultad privativa del Congreso que debe ejercerse mediante leyes, y que no hacerlo es desconocer el principio de legalidad en materia de impuestos. Es este el caso de la Sentencia del 6 de junio de 1913, en la cual la Corte declara inexequible el decreto ejecutivo 156 de 1913 por el cual se creaba la obligación de pago para obtener un servicio telegráfico en tiempos de paz, contraviniendo los Artículos 6 y 67 de la Constitución de 1886. Pero lo que hace realmente improcedente a este tributo creado en tiempos de paz es que es el Congreso quien tiene la facultad privativa para hacerlo, y es por ello que además debe hacerse mediante leyes. Así lo tenía estipulado el Ordinal 11 del Artículo 76 de la Constitución de 1886.

Asimismo, la Corte declara la inexequibilidad de impuestos creados por decreto cuando éstos a pesar de estar mencionados en una ley no estén desarrollados en su integridad por el legislador, lo que a juicio de la Corte equivale a la creación de un impuesto sin autorización previa del Congreso. En estas circunstancias, para la Corte no hay simple reglamentación por parte del Ejecutivo sino la creación de impuestos no suficientemente determinados por la ley, por lo que considera que el gobierno se arroga facultades que son privativas del Congreso conforme al Artículo 76 Ordinal 11 antes citado. Son estas las razones por las cuales la Corte Suprema declara inexequible el Decreto 899 de 1907 por exceder lo dispuesto por el legislador en la Ley 59 de 1905. Así lo resuelve la Corte en Sentencia de 14 de julio de 1913. 
La Corte Suprema no sostuvo esa misma tesis en la sentencia del 23 de junio de 1913. Y no lo hizo porque la indeterminación del tributo en este caso venía directamente del legislador. Los señores Sergio Martínez, Gabriel Pineda y Luis Forero piden que se declare inexequible el Artículo 8 de la Ley 18 de 1907 por delegar el congreso con su expedición su capacidad de imponer tributos en el ejecutivo. La Corte lo considera exequible porque el Artículo 1 de la ley en mención crea obligaciones tributarias de matrícula y registro y el Artículo 8 solo dice que el gobierno podrá fijar el monto del tributo pero no delega la capacidad de crear normas en el gobierno.

Lo anterior, a juicio de la Corte, va en consonancia con el numeral 9 del Artículo 76 que le permite al Congreso establecer competencias en cabeza del ejecutivo, siempre que no contravengan la órbita constitucional. Esta decisión genera una ardua polémica, suscitando un salvamento de voto conjunto por parte de los magistrados Ferrero, Rodríguez y Samper, quienes consideraron que el Artículo 8 de la Ley 18 de 1907 ha debido declararse inexequible por cuanto con él el congreso sí delega su competencia privativa de establecer las rentas nacionales consignada en el Artículo 76, Incisos 11 y 18. Para los magistrados que se apartan de la decisión mayoritaria, el Artículo 8 es inconstitucional porque el espíritu del Artículo 76, Numeral 11 es no sólo que el congreso establezca el impuesto sino que determine su cuantía con exactitud, y no hacerlo equivale a no haberlo creado.

Es interesante observar que la Corte no tiene el mismo rigor ni mide con igual rasero los decretos del ejecutivo que crean tributos, cuando éstos son el resultado de facultades pro tempore y extraordinarias que le otorga el Congreso, en virtud del ordinal 10 del Artículo 76 de la Constitución de 1886, al Presidente de la República. Es por esto que la Corte en el Acuerdo 42 de 6 de febrero de 1919 se abstiene de manera sorpresiva de declarar la inexequibilidad del Decreto 2089 de 1917 por medio del cual el ejecutivo reglamenta el cobro de impuestos y modifica los gravámenes previstos para un período fiscal.

Lo mismo ocurre en Sentencia del 25 de marzo de 1915, en la cual la Corte se abstiene de declarar inexequible los Artículos 3 y siguientes del Decreto Ejecutivo 161 de 1915. A juicio de la Corte, no son inexequibles porque "el legislador no permitió al gobierno decretar impuestos que a bien tuviera, ni lo dejó en libertad para fijar su cuantía," (Gaceta Judicial, 23: 342) porque la imposición de cualquier contribución debe estar sujeta a que las circunstancias lo hagan indispensable (guerra en Europa), y se necesite de medidas extraordinarias. Es por esto, continúa la Corte, por lo que no se señalan los nuevos impuestos, las fechas en que deben principiar a pagarse y no se precisa su tarifa. Para la mayoría de la Corte no es contrario a la Constitución que los impuestos puedan cobrarse de manera inmediata y no a los seis meses, por cuanto las extraordinarias facultades otorgadas con este Decreto al Presidente de la República así lo justifican. 
En enérgico salvamento de voto, los magistrados Tancredo Nanneti e Isaías Castro manifiestan que las normas acusadas han debido declararse inexequibles porque el Congreso delegó en el Presidente de la República atribuciones que él ni siquiera puede ejercer por ser contrarias al Artículo 69 del A.L 3 de 1910, que impone el tiempo de seis meses para que se haga efectivo un nuevo tributo, además de haber delegado atribuciones que le son privativas en virtud del Artículo 76 numeral 11. Para estos magistrados:

[...] aceptada la tesis de que el Congreso [...] puede revestir al Presidente de facultades que el primero no tiene o que no puede ejercer por prohibírselo la Constitución, se tendría que los constituyentes de 1886 dejaron al arbitrio de la mayoría del Congreso todo el capítulo de derechos civiles y garantías sociales, lo cual es inadmisible (Gaceta Judicial, 23: 348).

La sub-regla jurisprudencial de la Corte Suprema entre 1910 y 1920, en materia de impuestos creados por decreto, es la de que no es posible que el ejecutivo cree nuevos impuestos con la expedición de decretos, a menos que sea el mismo Congreso el que delegue esta facultad en el Presidente de la República. Sub-regla que tiene el gran problema de que si la función de crear nuevos tributos es privativa del Congreso no se ve cómo pueda delegarla y establecerla en cabeza de otra rama del poder público. Cuestionamiento que se plantea de manera repetida en las sentencias expuestas por los magistrados que se apartan de la posición mayoritaria.

\section{Derechos adquiridos y de propiedad}

En los primeros 20 años de su vigencia, la acción pública de inconstitucionalidad fue utilizada de manera recurrente por ciertos grupos sociales que acudían a ella para demandar leyes o decretos que consideraban que lesionaban sus derechos adquiridos; bien sea porque les ocasionaban un detrimento en su patrimonio o desmejoraban las condiciones de explotación de una actividad económica, o en algunos casos alegaban simplemente que con la expedición de ciertas normas habían tenido lugar variaciones en las reglas de juego que los actores consideraban injustas y contrarias a la Constitución.

Los principales actores en este escenario constitucional fueron militares, particulares que litigaban temas pensionales, y empresarios.

\section{Militares}

Los militares en su mayoría acudían a la Acción para demandar leyes y decretos que modificaban los procedimientos para el pago de salarios, pensiones, recompensas y ceses militares. 
Las Sentencias de 25 de julio de 1912, de 16 de diciembre de 1914 y el Acuerdo 12 de 6 de junio de 1916, son ejemplos de estos casos. En la primera de estas sentencias, los actores Luis José Barros, Jorge Méndez, Pedro A. Peña y Pedro Cortés piden que se declare inconstitucional el Decreto Ejecutivo 1565 de 1906. La Corte Suprema acoge la petición de los demandantes declarando inexequible el mencionado decreto porque desconoce los derechos adquiridos reconocidos en las Leyes 84 de 1890 y 149 de 1896, que otorgaban el derecho de que las recompensas militares se pagaran en moneda legal, cuestión que el decreto contrariaba cuando disponía que se podía hacer con vales. Para la Corte no cabe la menor duda que la variación que hace la norma acusada atenta contra el Artículo 31 de la Constitución que protege los derechos adquiridos.

En Sentencia de 16 de diciembre de 1914, el ciudadano Demetrio Fierro ataca varias normas por considerar que atentan contra los derechos adquiridos de los militares. La Corte declara inexequible el Artículo 2 del decreto legislativo 9 de 1906 por desconocer derechos adquiridos cuando dispone que se termina el plazo para el registro de ceses militares a partir de la expedición de este decreto, y no pudiendo estos registrarse desde entonces, no serán pagados, con lo cual se desconoce el derecho adquirido por lo tenedores de ellos, derecho que se adquirió por los militares que prestaron su servicios al ejército, y cuyo pago ha garantizado la Constitución y las leyes.

Es también inexequible, dice la Corte, el Artículo 4 de la Ley 3 de 1907 cuando establece que la deuda de tesorería que no se hubiera sometido a ciertas formalidades quedaba sin valor, desconociendo derechos de los militares reconocidos en los Decretos Legislativos 6 y 37 de 1905, y por la Ley 3 de ese mismo año. Asimismo, es inexequible el Decreto 76 de 1911 por cuanto suspende el pago de ceses militares y de documentos de esta especie que representen sueldos o raciones del ejército entre los años de 1899 y 1903 hasta que el cuerpo legislativo resuelva lo contrario, lo que es contrario a los derechos adquiridos consagrados en el Artículo 31 de rango superior.

Se apartan de la decisión mayoritaria los magistrados Nannetti y Villegas. El primero de ellos, juzga que someter los documentos que comprueban un derecho a ciertas formalidades que tienen por objeto establecer la autenticidad de tales documentos, y señalar un término para que se llenen, no es vulnerar un derecho adquirido sino regular el ejercicio del mismo. Por su parte, Villegas expresa que los derechos adquiridos deben estar reconocidos en leyes civiles por lo que no basta el simple hecho de prestar el servicio militar para exigirle al poder judicial el pago de ceses militares.

El señor Samuel Cortés demanda los Artículos 4 y 5 de la Ley 87 de 1915 alegando que son inconstitucionales porque contravienen el Artículo 169 de la Constitución que no permite se prive a los militares de grados, honores y pensiones sino en los casos y del modo que determine la ley. La Corte, en el 
Acuerdo 12 de 6 de junio de 1916, atiende la petición del demandante declarando los artículos mencionados inexequibles, y afirma que permitir el recorte de las pensiones o la disminución de éstas sería nefasto, porque los militares no tendrían certeza de las garantías que les provee la ley.

Es curioso que el General Laureano García demande el decreto que ordena su retiro del cuerpo castrense. La Corte con ponencia del Magistrado Gnecco Laborde declara que no hay lugar a declarar la inexequibilidad del decreto 1217 de 1916 porque éste sólo dispone el retiro del general, competencia que le es atribuida al Presidente de la República por la Constitución. Tampoco es posible declarar una norma inexequible por contravenir la Ley 71 de 1915, que además no ha sido violada. Llama la atención que un general de la República quiera controvertir en un escenario judicial una decisión discrecional del Presidente, litigando en causa propia.

\section{Pensiones}

Los ciudadanos particulares hicieron uso de la acción pública de inconstitucionalidad para exigir que se les pagaran sus pensiones en oro, y para atacar leyes que suspendían el pago de pensiones reconocidas por el Estado, lo que consideraban un atentado contra los derechos adquiridos. La posición mayoritaria de la Corte sostiene que la suspensión en el reconocimiento de las pensiones no atenta contra los derechos adquiridos; tan sólo es una restricción que bien puede hacer el legislador.

El ciudadano Arsenio Gómez demanda el Artículo 2 de la Ley 37 de 1904 sobre pensiones. Alega el actor que contrario a lo que dispone esta norma el Estado está obligado a cancelar las pensiones en oro, por lo que pide se le declare inexequible. La Corte en Sentencia de 11 de diciembre de 1913 no acoge los planteamientos del demandante porque considera que no es cierto que las pensiones reconocidas con anterioridad al artículo acusado tuvieran que pagarse en oro, como lo pretende el solicitante, por cuanto conforme a la Ley 33 de 1903 el papel moneda conservo su poder liberatorio, es decir, que pese a esa ley subsistió el curso forzoso del billete nacional. Así lo dispuso el Artículo 4 (ordinal 5) de la Ley 33 de 1905 cuando dispone que "toda obligación que se contraiga en moneda corriente o en que no se expresa moneda determinada, se entenderá contraída y pagada de curso forzoso". No habiendo la ley que dispusiera pagar las pensiones en oro, debe entenderse que son pagaderas en billetes nacionales.

En Acuerdo 39 de 25 de octubre de 1918, la Corte Suprema no atiende las peticiones de los demandantes Manuel Robles y Tulio A. Forero en el sentido de que se declare inexequible el Artículo 7 de la Ley 80 de 1916 por considerar que las suspensiones en el reconocimiento de las pensiones que esta norma ordena atenta contra los derechos adquiridos de los pensionados. Para la Corte, la norma acusada es exequible por cuanto no afecta derecho adquirido alguno 
de carácter pensional; lo que hace es suspender el reconocimiento de pensiones atendiendo a las necesidades del tesoro público.

El magistrado Méndez salva su voto argumentando en forma correcta que el Artículo 31 "ampara los derechos adquiridos, no solamente contra leyes que los desconozcan, sino también contra aquellas que de cualquier manera los vulneren, esto es, sin desconocer su existencia, puedan sin embargo perjudicarlos [...]" (Gaceta judicial, 26: 378). A mi modo de ver, el salvamento de voto es acertado porque la suspensión no es temporal y se cierra la vía administrativa para el reconocimiento de pensiones sin abrir ninguna otra, haciendo nugatorios los derechos adquiridos de carácter pensional que detentan los ciudadanos.

La Corte Suprema reitera su tesis en el Acuerdo 4 de 4 de julio de 1922. La Corporación decide denegar la petición del ciudadano Jorge Isaacs de que se declare la inconstitucionalidad de la Ley 7 $\stackrel{a}{\text { a de }} 1922$ que suspende los derechos pensionales de los militares. Para la Corte, la ley acusada es exequible porque no desconoce los derechos pensionales de los militares reconocidos por el Artículo 11 de la Ley 71 de 1915 en su ordinal 1, por cuanto la ley acusada no los hace desaparecer sino que tan solo los suspende. Por lo demás, dice la Corte, el Congreso no excede sus competencias porque la suspensión está dentro de lo que compete a este organismo para reformar las leyes

Pareciera que la Corte sólo encontraría probada una afectación de los derechos adquiridos de carácter pensional cuando el legislador los desconociera de manera expresa, es decir, cuando ordenara la eliminación de estos o tomara la decisión explícita de no cumplir con el pago de los rubros de ese carácter. La Corporación no estaba dispuesta a aceptar, a nuestro juicio sin acertar, que más allá de un directo desconocimiento de las pensiones, hay formas disímiles de afectar estos derechos, como cuando ellos se vulneran restringiéndose a su mínima expresión, aunque se crea que existen nominalmente, lo cual lo torna nugatorios para sus titulares.

\section{Empresarios}

Por razones obvias fueron los empresarios quienes más utilizaron la acción para atacar normas que ellos consideraban que les causaban detrimentos patrimoniales, o que modificaban las condiciones contractuales acordadas con el Estado para la explotación de una actividad económica, alegando siempre un desconocimiento sin justa causa por parte de las normas acusadas de los derechos adquiridos, y en ciertos casos de los derechos de propiedad.

Las Sentencias de 30 de octubre de 1912, de 21 de noviembre de ese mismo año y de 12 de junio de 1913 son ejemplos de decisiones en las que los actores acuden a la acción para pedir la inexequibilidad de decretos que consideraban vulneraban sus derechos adquiridos causándoles un perjuicio económico que no debían soportar. En la primera de estas sentencias, el demandante pide que 
se declare inexequible el Artículo 1 del Decreto 1042 de 1905 argumentando que este decreto suspende el pago de créditos que la Nación le adeuda a los transportadores por concepto de contratos de transporte y de arrendamiento celebrados con este gremio. La Corte declara inexequible el Artículo 1 del decreto mencionado por desconocer las acreencias que se fundamentan en los decretos 886 y 1014 de 1902 por cuanto los transportadores tienen derecho a que se les pague sus servicios en virtud de las leyes civiles que reglamentan los contratos de transporte y arrendamiento, derechos que fueron desconocidos por el Decreto 1042 al disponer que el pago de los créditos quedaban suspendidos, por lo que no serían pagados, desconociendo los derechos adquiridos protegidos por la Ley Civil y el Artículo 31 de la Constitución, además de no tener razones de interés público para hacerlo.

En Sentencia de 21 de noviembre de 1912, los demandantes atacan el Decreto Legislativo 40 de 1905 y la Ley 6 de 1905 que reglamentaban el tema de la desecación de lagunas, alegando que estas normas utilizaban el fenómeno natural de la desecación de los cuerpos de agua para adjudicarle terrenos de propiedad privada al Estado por el solo hecho de que ocurra este fenómeno. La Corte acoge los planteamientos de los demandantes sin mayor discusión declarando las normas inexequibles por considerar que en virtud de sus disposiciones pasan las tierras de dueños particulares al dominio de la Nación, y por consiguiente se desconoce y vulnera el derecho de los propietarios consagrado en el Artículo 32 de la Constitución y el 31 referente a derechos adquiridos.

Los señores Gregorio y Domingo Arboleda demandan varias disposiciones del Código de Minas por considerarlas violatorias de los Artículos 31, 32 y el Artículo 5 del A.L 3 de 1910 porque a juicio de los demandantes estas normas del Código de Minas establecen circunstancias bajo las cuales se podrían perder los derechos de explotación sobre las minas, contrariando los derechos adquiridos y de propiedad que ciertos ciudadanos tienen sobre ellas. La Corte en Sentencia de 12 de junio de 1913 expresa que las normas del Código de Minas no violan los Artículos 31, 32 y 5 del A.L 3 de 1910 porque desde antes de expedido este Código existían especiales circunstancias, como la no explotación de las minas, bajo las cuales se podían perder los beneficios sobre ellas, y el Código actual lo que ha hecho es ampliar esas causales, estableciendo que el no pago de un impuesto sobre las minas puede acarrear la pérdida del derecho a explotarlas.

El Acuerdo 7 de 17 de mayo de 1921 y las Sentencias de 28 de julio y 18 de noviembre de 1924 nos muestran cómo para la época los empresarios y sociedades comerciales que habían suscrito contratos con el Estado para la explotación de actividades económicas utilizaban la acción pública para controvertir las decisiones del Estado materializadas en leyes y decretos que hacían variaciones en las condiciones contractuales pactadas entre las partes. 
En la primera de esas decisiones, el señor Juan Samper Sordo demanda los Artículos 7 y 8 de la Ley 108 de 1919 sobre emisión de cédulas hipotecarias argumentando que dichas normas contemplaban variaciones en los contratos celebrados entre los particulares y el Estado para el desarrollo de la actividad bancaria. Para la Corte, el Artículo 7 es exequible porque sólo dispone que las cédulas hipotecarias que emitieran los bancos tuvieran como anexos los cupones de interés sin importar el valor monetario representado en ellas, por lo que no contemplan variación alguna en los contratos celebrados.

Por el contrario, los cambios que hace el Artículo 8 de la ley mencionada sí alteran los tiempos que tiene los bancos para hacer las amortizaciones de crédito, creando una situación más onerosa para éstos, y alterando los contratos vigentes sobre la materia. Por lo anterior, el Artículo 8 es contrario al Artículo 31 y al 5 del A.L 3 de 1910 que protegen los derechos adquiridos. El magistrado Rodríguez salva voto afirmando que el Artículo ha debido declararse exequible por cuanto los contratos celebrados por el Gobierno con los bancos particulares para emitir y poner en circulación cédulas son concesiones legales sujetas a cambios y a reglamentaciones por parte del legislador.

En Sentencia de 28 de julio de 1924, los actores Samuel Montaña, C. Carrizosa, Frank A. Koppel \& Compañía, H. Machado L, F. Pineda López, quienes dicen ser representantes de la empresa Tranvía y del Acueducto Municipal, piden que se declare inexequible el Artículo 28 de la Ley 109 de 1923, argumentando que esta norma quiere hacer pagar derechos de importación a quienes están exentos de pagarlos por voluntad estatal manifestada en un contrato.

La petición de los demandantes prospera, porque a juicio de la Corte es inexequible el artículo acusado si se tiene en cuenta que:

[...] quien está eximido, en razón de un contrato celebrado con el Estado, de pagar derechos de importación, no tiene porque ser sometido al gravamen del que se ha hecho referencia, gravamen que para él significa pérdida de los intereses del capital pagado, amén de los perjuicios que puedan sobrevenirle por no poder retirar el objeto oportunamente de la Aduana" (Gaceta Judicial, 31: 53).

Para la Corte es claro que se viola un derecho adquirido de los particulares que surge de la suscripción de un contrato con el Estado.

José Francisco Riascos y la Sociedad José F. Riascos \& Compañía demandan el Artículo 10 de la Ley 64 de 1923, argumentando que esta norma desconoce los términos de los contratos celebrados entre el Estado y los particulares para la explotación de la loterías departamentales. En Sentencia de 18 de noviembre de 1924, la Corte acoge los argumentos del actor declarando inexequible el Artículo 10 de la ley mencionada, por cuanto considera que el artículo deman- 
dado es modificatorio de los pactos contractuales celebrados por los particulares con el Estado cuando redefine los porcentajes de los premios a entregar a los ganadores y del dinero que corresponde a las entidades de derecho público. Además, la intervención o modificación no obedece a la moralidad, seguridad o salubridad pública.

La discusión de fondo que se da a lo largo de las decisiones anteriormente expuestas es si las condiciones de explotación de una actividad económica dada en concesión a los particulares, o el establecimiento de exenciones tributarias a favor de empresarios por el Estado, están sujetas al vaivén de los cambios legales que haga el Congreso, o si el desarrollo de las mismas no puede ser modificado hasta tanto no expire el período contractual pactado. En todas las sentencias expuestas triunfa la segunda tesis, con la excepción del salvamento de voto del magistrado Rodríguez que en el Acuerdo 7 de 17 de mayo 1921 sostiene que los contratos celebrados entre el Estado y los particulares son concesiones legales sujetas a cambios y reglamentaciones por parte del legislador.

\section{Conclusiones}

Los primeros 20 años de jurisprudencia constitucional revelan algo sorprendente: la acción pública de inconstitucionalidad fue utilizada en proporción bajísima en la defensa de las conquistas democráticas alcanzadas en el consenso de 1910. Es decir, que los casos litigados y decididos entre 1910 y 1930 no correspondieron, en su mayoría, a las grandes preocupaciones y discusiones que tuvo el constituyente de la época.

Solo fueron tres los escenarios constitucionales litigados ante la Corte Suprema, considerados de vital importancia para mantener la paz entre los partidos políticos y la defensa del consenso alcanzado en la Asamblea Nacional, a saber: 1. Separación de las ramas del poder público e independencia de las entidades de la administración; 2. Garantías electorales y libertad de prensa; 3 . Tensiones entre centralización y descentralización y división territorial.

La Corte Suprema de Justicia sabía que permitir que se atentara contra las garantías establecidas por el constituyente en los tres aspectos mencionados podía significar el regreso a los conflictos fratricidas de antaño. Por ello no dudó en declarar inconstitucionales las leyes y decretos que contravenían el principio de separación de poderes, las garantías electorales y la libertad de prensa. Es claro que estos escenarios gozaban de protección constitucional mucho antes de creada la acción pública, pero solo con ella se hicieron vinculantes para la actuación de los poderes públicos.

No ocurrió lo mismo con las normas demandadas que se ocupaban de la división territorial y de la tensión entre centralización y descentralización, porque aun cuando era un tema de gran preocupación en la época, el constituyente nada dispuso al respecto, siendo imposible para la Corte declarar inconstitu- 
cionales normas que no eran contrarias al texto constitucional. Por medio de leyes y decretos siguió afianzándose un acérrimo centralismo en el país sin que los ciudadanos por medio de la acción pública pudieran detenerlo.

Por el contrario, tuvo lugar una explosión litigiosa en torno a nuevos temas que se sustraían del gran objetivo político con el que se creó la acción. Los actores no pretendían con sus demandas defender los acuerdos de paz y las garantías democráticas acordadas por los partidos políticos en la Asamblea Nacional de 1910. Sus esfuerzos estuvieron reconducidos a demandar leyes y decretos que consideraban que atentaban contra la libertad de empresa, a atacar la constitucionalidad de tributos e impuestos, y a la defensa de derechos adquiridos y de propiedad.

La naciente clase empresarial colombiana (Dávila, 2003) encontró en la acción pública un mecanismo para controvertir decisiones del Estado materializadas en leyes y decretos que juzgaba como injerencias injustificadas en la actividad económica. Los empresarios, argumentando que se violaba el Artículo 44 de la Constitución de 1886 que consagraba la libertad de empresa y el A.L 1 de 1918 que solo permitía que se interviniera en las actividades económicas privadas bajo las circunstancias de moralidad, salubridad y seguridad públicas; demandaban disposiciones que creaban monopolios y normas que consideraban les hacían más onerosa la explotación de su actividad.

Distintos actores acudieron a la acción para atacar la constitucionalidad de impuestos y tributos argumentando que no le era posible al ejecutivo crearlos por decreto, toda vez que esta es una función privativa del Congreso. En los casos en que se atacaba la constitucionalidad de tributos creados mediante leyes, se aducía que no era posible crear tributos en abstracto sin la determinación exacta de los elementos de la obligación tributaria. Asimismo, se recurrió a la acción pública para defender derechos adquiridos por parte de militares, pensionados y empresarios. Alegaban los actores que se les causaban detrimentos injustificados en sus patrimonios desconociendo derechos subjetivos reconocidos en leyes civiles, o el desconocimiento por parte del legislador de los pactos contractuales celebrados con el Estado para la explotación de una actividad económica.

La acción pública se convirtió con gran rapidez en un mecanismo eficaz por medio del cual los empresarios controvertían las reglamentaciones legales que el Estado hacía de sus actividades económicas. Alegando la violación de derechos subjetivos protegidos en el texto constitucional, los empresarios utilizaron este nuevo espacio institucional para manifestar su desacuerdo con leyes y decretos que consideraban que excedían el margen de intervención permitido por la Constitución, que hacían sus actividades económicas más onerosas sin razones legítimas, o que variaban los términos definidos con el Estado en contratos estatales de concesión. 
La jurisprudencia constitucional de la Corte Suprema de Justicia entre 1910 y 1930 revela que la acción pública fue un instrumento jurídico valioso para la naciente clase empresarial colombiana, que buscaba controvertir las decisiones estatales materializadas en leyes y decretos, que consideraban que hacían más gravosa la explotación de una determinada actividad económica, o por medio de los cuales el Estado intervenía el mercado en forma injustificada, por medio de regulaciones excesivas o la imposición de tributos que no contaban con el debido soporte legal.

La acción que nació para la defensa del consenso alcanzado en la Asamblea Nacional de 1910, una vez creada se convirtió en un mecanismo eficaz para la defensa de derechos subjetivos amparados por el ordenamiento jurídico colombiano, que se sustraían de las preocupaciones políticas que llevaron a la convocatoria de la Asamblea Nacional, y que excedían claramente los objetivos para los que fue creada la acción pública de inconstitucionalidad.

\section{Referencias}

Libros

Bravo Arteaga, J. R. (1997). Nociones fundamentales de derecho tributario. Bogotá: Ediciones Rosaristas.

Cinep, 1998. Colombia: país de regiones. Bogotá: Cinep.

Correa Uribe, F. (1996). Republicanismo y reforma constitucional. Medellín: Universidad de Antioquia.

Dávila Ladrón de Guevara, C. (2003). Empresas y empresarios en la historia de Colombia, Siglos XIX y XX: una colección de estudios recientes. Bogotá: Ediciones Uniandes.

Rodríguez Peñaranda, M. L. (2005). Minorías, acción pública de inconstitucionalidad y democracia deliberativa. Bogotá: Universidad Externado de Colombia.

\section{Sentencias}

Corte Suprema de Justicia, sentencia de 25 de julio de 1912, Sala de Negocios Generales, M.P: Bartolomé Rodríguez, Gaceta Judicial, tomo 21, No. 1040 1090, 1912-1913.

Corte Suprema de Justicia, sentencia de 30 de octubre de 1912, Sala de Negocios Generales, M.P: Suárez Murillo, Gaceta Judicial, tomo 21, No. 1040-1090, 1912-1913. 
Corte Suprema de Justicia, sentencia de 21 de noviembre de 1912, Sala Plena, M.P: Bartolomé Rodríguez, Gaceta Judicial, tomo 22, No. 1091-1146, 19131914.

Corte Suprema de Justicia, sentencia de 5 de diciembre de 1912, Sala Plena, M.P: Suárez Murillo, Gaceta Judicial, tomo 25, No. 1257-1332, 1916.

Corte Suprema de Justicia, sentencia de 24 de abril de 1913, Sala de Negocios Generales, M.P: Augusto N. Samper, Gaceta Judicial, tomo 22, No. 1091-1146, 1913-1914.

Corte Suprema de Justicia, sentencia de 6 de junio de 1913, Sala de Negocios Generales, M.P: Suárez Murillo, Gaceta Judicial, tomo 22, No. 1091-1146, 1913-1914.

Corte Suprema de Justicia, sentencia de 12 de junio de 1913, Corte Plena, M.P: Augusto N. Samper, Gaceta Judicial, tomo 26, No. 1333-1383, 1917-1919.

Corte Suprema de Justicia, sentencia de 23 de junio de 1913, Sala Plena, M.P: Augusto N. Samper, Gaceta Judicial, tomo 23, No. 1147-1204, 1914-1915.

Corte Suprema de Justicia, salvamento de voto de sentencia de 23 de junio de 1913, M.P: Emilio Ferrero, Bartolomé Rodríguez y Augusto N. Samper, Gaceta Judicial, tomo 23, No. 1147-1204, 1914-1915.

Corte Suprema de Justicia, sentencia de 12 de julio de 1913, Sala de Negocios Generales, M.P: Suárez Murillo, Gaceta Judicial, tomo 22, No.1091-1146, 1913-1914.

Corte Suprema de Justicia, sentencia de 14 de julio de 1913, Sala de Negocios Generales, M.P: Augusto N. Samper, Gaceta Judicial, tomo 22, No.1091-1146, 1913-1914.

Corte Suprema de Justicia, sentencia de 2 de septiembre de 1913, Sala de Negocios Generales, M.P: Rodríguez P., Gaceta Judicial, tomo 22, No.1091-1146, 1913-1914.

Corte Suprema de Justicia, sentencia de 23 marzo de 1914, Sala de Negocios Generales, M.P: Augusto N. Samper, Gaceta Judicial, tomo 31, No. 1595-1643, 1924-1925.

Corte Suprema de Justicia, sentencia de 16 de diciembre de 1914, Sala Plena, M.P: Augusto N. Samper, Gaceta Judicial, tomo 23, No. 1147-1204, 1914-1915. 
Corte Suprema de Justicia, sentencia de 17 de noviembre de 1914, Sala Plena, M.P: Suarez Murillo, Gaceta Judicial, tomo 23, No. 1147-1204, 1914-1915.

Corte Suprema de Justicia, sentencia de 25 de marzo de 1915, Sala Plena, M.P: Elías Romero, Gaceta Judicial, tomo 23, No. 1147-1204, 1914-1915.

Corte Suprema de Justicia, salvamento de voto de sentencia de 25 de marzo de 1915, M.P: Tancredo Nannetti e Isaías Castro, Gaceta Judicial, tomo 23, No. 1147-1204, 1914-1915.

Corte Suprema de Justicia, sentencia de 15 de julio de 1915, Sala Plena, M.P: Augusto N. Samper, Gaceta Judicial, tomo 23, No. 1147-1204, 1914-1915.

Corte Suprema de Justicia, Acuerdo 12 de 6 de junio de 1916, Sala Plena, M.P: Manuel N. Angarita, Gaceta Judicial, tomo 25, No. 1257-1332, 1916.

Corte Suprema de Justicia, Acuerdo 30 de 29 de septiembre de 1917, Sala Plena, M.P: Gonzalo Pérez, Gaceta Judicial, tomo 26, No. 1333-1383, 1917-1919.

Corte Suprema de Justicia, salvamento de voto de Acuerdo 30 de 29 de septiembre de 1917, Sala Plena, M.P: Rodríguez P., Gaceta Judicial, tomo 26, No. 1333-1383, 1917-1919.

Corte Suprema de Justicia, salvamento de voto de Acuerdo 36 de 27 de junio de 1918, M.P: Germán D. Pardo, Augusto N. Samper y Francisco E. Diago, Gaceta Judicial, tomo 26, No. 1333-1383, 1917-1919.

Corte Suprema de Justicia, salvamento de voto de Acuerdo 40 de 12 de diciembre de 1918, Sala Plena, M.P: Juan N. Méndez, Gaceta Judicial, tomo 26, No. 1333-1383, 1917-1919.

Corte Suprema de Justicia, Acuerdo 39 de 25 de octubre de 1918, Sala Plena, M.P: José Gnecco Laborde, Gaceta Judicial, tomo 26, No. 1333-1383, 1917 1919.

Corte Suprema de Justicia, salvamento de voto de Acuerdo 39 de 25 de octubre de 1918, M.P: Juan N. Méndez, Gaceta Judicial, tomo 26, No. 1333-1383, 1917-1919.

Corte Suprema de Justicia, Acuerdo 42 de 6 de febrero de 1919, Sala Plena, M.P: Francisco Diago, Gaceta Judicial, tomo 27, No. 1384-1435, 1919-1920.

Corte Suprema de Justicia, Acuerdo 54 de 12 de diciembre de 1919, Sala Plena, M.P: Marceliano Pulido, José Miguel Arango, Juan N. Méndez, Tancredo 
Nannetti, Germán D. Pardo, Gonzalo Pérez y Bartolomé Rodríguez, Gaceta Judicial, tomo 27, No. 1384-1435, 1919-1920.

Corte Suprema de Justicia, Acuerdo 5 de 1 de marzo de 1921, Sala Plena, M.P: Rodríguez P., Gaceta Judicial, tomo 28, No. 1436-1487, 1920-1921.

Corte Suprema de Justicia, Acuerdo 7 de 17 de mayo de 1921, Sala Plena, M.P: Ramón Rodríguez Diago, Gaceta Judicial, tomo 28, No. 1436-1487, 1920-1921.

Corte Suprema de Justicia, Acuerdo 10 de 30 de septiembre de 1921, Sala Plena, M.P: Ramón Rodríguez Diago, Gaceta Judicial, tomo 29, No. 1488-1540, 1921-1923.

Corte Suprema de Justicia, Acuerdo 11 de 22 de octubre de 1921, Sala Plena, M.P: Luis F. Rosales, Gaceta Judicial, tomo 29, No. 1488-1540, 1921-1923.

Corte Suprema de Justicia, Acuerdo 3 de 24 de abril de 1922, Sala Plena, M.P: Bartolomé Rodríguez, Gaceta Judicial, tomo 29, No. 1488-1540, 1921-1923.

Corte Suprema de Justicia, Acuerdo 4 de 4 de julio de 1922, Sala Plena, M.P: Bartolomé Rodríguez, Gaceta Judicial, tomo 29, No. 1488-1540, 1921-1923.

Corte Suprema de Justicia, sentencia de 26 de febrero de 1923, Sala Plena, M.P: Rodríguez P., Gaceta Judicial, tomo 30, No. 1541-1592, 1923-1924.

Corte Suprema de Justicia, sentencia de 5 de abril de 1923, Sala Plena, M.P: Luis F. Rosales, Gaceta Judicial, tomo 29, No. 1488-1540, 1921-1923.

Corte Suprema de Justicia, sentencia de 28 de julio de 1924, Sala Plena, M.P: Luis F. Rosales, Gaceta Judicial, tomo 31, No. 1595-1643, 1924-1925.

292 Corte Suprema de Justicia, sentencia 18 de noviembre de 1924, Sala Plena, M.P: Luzardo Fortoul, Gaceta Judicial, tomo 31, No. 1595-1643, 1924-1925.

Corte Suprema de Justicia, sentencia de 9 de agosto de 1924, Sala Plena, M.P: Ramón Rodríguez Diago, Tancredo Nannetti, José Miguel Arango, Alberto Goenaga, Julio Luzardo Fortoul, Marceliano Pulido, Luis F. Rosales, Juan C. Trujillo, Gaceta Judicial, tomo 31, No. 1593-1643, 1924-1925.

Corte Suprema de Justicia, sentencia de 14 de noviembre de 1924, Sala Plena, M.P: Ramón Rodríguez Diago, Tancredo Nannetti, José Miguel Arango, Alberto Goenaga, Julio Luzardo Fortoul, Juan N. Méndez, Marceliano Pulido, Luis F. Rosales, Juan C. Trujillo, Gaceta Judicial, tomo 31, No. 1595-1643, 1924-1925.

Corte Suprema de Justicia, sentencia de 25 de septiembre de 1925, Sala Plena, M.P: Luzardo Fortoul, Gaceta Judicial, tomo 32, No. 1644-1695, 1925-1926. 
Corte Suprema de Justicia, sentencia de 4 de diciembre de 1925, Sala Plena, M.P: Francisco Tafur A., Gaceta Judicial, tomo 32, No. 1644-1695, 1925-1926.

Corte Suprema de Justicia, sentencia de 12 de diciembre de 1925, Sala Plena, M.P: Luis F. Rosales, Gaceta Judicial, tomo 32, No. 1644-1695, 1925-1926.

Corte Suprema de Justicia, sentencia de 17 de agosto de 1926, Sala Plena, M.P: Luzardo Fortoul, Gaceta Judicial, tomo 33, No. 1696-1746, 1927.

Corte Suprema de Justicia, salvamento de voto de sentencia de 17 de agosto de 1926, M.P: Parmenio Cárdenas, Gaceta Judicial, tomo 33, No. 1696-1746, 1927. 
